\title{
Korelasi Kadar Feritin dengan Profil Lipid pada Penyandang Talasemia Beta Mayor Anak
}

Mutiara Rahmani, Lelani Reniarti, Kusnandi Rusmil

Departemen Ilmu Kesehatan Anak Fakultas Kedokteran Universitas Padjadjaran/RSUP Dr. Hasan Sadikin, Bandung

Latar belakang. Talasemia beta mayor merupakan penyakit genetik dengan gangguan sintesis rantai globin yang menimbulkan eritopoiesis tidak efektif sehingga membutuhkan transfusi darah rutin. Terapi tersebut menyebabkan kelebihan besi di berbagai organ termasuk di hati dan pankreas yang memengaruhi enzim hepatik lipase yang mengatur regulasi metabolisme lipid.

Tujuan. Mengetahui korelasi kadar feritin dengan profil lipid pada penyandang talasemia beta mayor anak.

Metode. Penelitian observasional analitik dengan rancang potong lintang, dilaksanakan November - Desember 2018. Subjek adalah penyandang talasemia beta mayor di Rumah Sakit Hasan Sadikin, secara consecutive sampling. Dilakukan pemeriksaan serum feritin, trigliserida, kolesterol total, low density lipoprotein (LDL), dan high density lipoprotein (HDL). Uji statistik menggunakan uji korelasi rank Spearman dengan kemaknaan nilai $\mathrm{p}<0,05$.

Hasil. Terdapat sampel sebanyak 40 penderita talasemia beta mayor, 20 perempuan dan 20 laki-laki. Rerata serum feritin 4328,2 $\mathrm{mcg} / \mathrm{L}$, kolesterol total 93,78 mg/dl, HDL 20,65 mg/dl, LDL 52,95 mg/dl, dan trigliserida 154,95mg/dl. Tidak didapatkan korelasi antara feritin dengan kolesterol total dan LDL $(\mathrm{p}>0,05)$. Terdapat korelasi antara kadar feritin terhadap kadar serum kolesterol HDL dan trigliserida $(r=-0,349, p=0,029$ dan $r=0,460, p=0,003)$

Kesimpulan. Terdapat korelasi negatif antara kadar feritin terhadap kolesterol HDL dan korelasi positif terhadap trigliserida. Semakin tinggi feritin, semakin rendah HDL, semakin tinggi trigliserida. Sari Pediatri 2019;21(3):189-94

Kata kunci: feritin, profil lipid, talasemia beta mayor, anak

\section{Correlation between Ferritin an d Lipid Profile in Children with Beta Thalassemia Major}

Mutiara Rahmani, Lelani Reniarti, Kusnandi Rusmil

Background. Beta thalassemia major is genetic disorder in globin chain synthesis which caused uneffective erythropoiesis therefore routine blood transfusion is needed. This therapy causes iron overload in many organs including liver and pancreas which influenced lipase hepatic enzyme who regulate lipid metabolism.

Objective. To know correlation between ferritin and lipid profile in children with beta thalassemia major

Methods. An observational analytic study with cross-sectional design was conducted in November-December 2018. The subjects were beta thalassemia major patients in Rumah Sakit Hasan Sadikin, selected by consecutive sampling. We examined ferritin, triglyceride, total cholesterol, low density lipoprotein (LDL), dan high density lipoprotein (HDL). The Spearman rank test was used to analyze subjects, significance value of $\mathrm{p}<0.05$.

Result. There were 40 subjects consist of 20 boys and 20 girls. Mean ferritin serum was $4328.2 \mathrm{mcg} / \mathrm{L}$, total cholesterol was 93.78 $\mathrm{mg} / \mathrm{dl}$, HDL was $20.65 \mathrm{mg} / \mathrm{dl}$, LDL was $52.95 \mathrm{mg} / \mathrm{dl}$, dan triglyceride was $154.95 \mathrm{mg} / \mathrm{dl}$. There is no correlation between ferritin with LDL and total cholesterol $(\mathrm{p}>0.05)$. There was significant correlation ferritin with HDL cholesterol and triglyceride $(r=-0.349$, $\mathrm{p}=0.029$ and $\mathrm{r}=0.460, \mathrm{p}=0.003)$.

Conclusion. There is negative correlation between ferritin with HDL and positive correlation with triglyceride. Increasing ferritin is correlated with decreasing HDL and increasing triglyceride. Sari Pediatri 2019;21(3):189-94

Keywords: ferritin, lipid profile, beta thalassemia major, children

Alamat korespondensi: Lelani Reniarti. Departemen Ilmu Kesehatan Anak Fakultas Kedokteran UNPAD Gedung Kenanga Lantai 3, Jl. Pasteur No.38, Bandung 40163. Email: lelanir@yahoo.com 
Mutiara Rahmani dkk: Korelasi kadar feritin dengan profil lipid pada penyandang talasemia beta mayor anak

$\mathrm{T}$ alasemia beta mayor merupakan penyakit genetik terbanyak di dunia yang dapat meningkatkan angka kesakitan, kematian, serta memerlukan perhatian dan biaya yang besar. Pada pasien talasemia beta mayor, sintesis rantai globin terganggu yang menyebabkan terjadi proses hemolisis lebih cepat dan menimbulkan eritropoiesis tidak efektif sehingga pasien membutuhkan transfusi darah secara rutin. ${ }^{1-3}$ Terkait hal itu, terapi tersebut dapat menyebabkan kelebihan zat besi dan morbiditas, seperti kerusakan pada hati dan pankreas. ${ }^{4,5}$ Agar terhindar dari komplikasi tersebut, penyandang talasemia harus mempertahankan kadar hemoglobin pretransfusi 9-10 g/dl dan mengonsumsi kelasi besi secara teratur. Dalam beberapa dekade terakhir, kombinasi transfusi darah dan terapi kelasi besi telah meningkatkan kualitas hidup penyandang talasemia beta mayor. ${ }^{6-10}$

Kerusakan hati pada talasemia yang mengakibatkan disregulasi lipid disebabkan oleh berbagai kondisi meliputi peningkatan aktivitas eritropoiesis, pembentukan radikal bebas dan aktivasi sistem makrofag dengan pelepasan sitokin. ${ }^{11}$ Dua faktor penting yang mengakibatkan kelebihan besi adalah transfusi darah berulang dan peningkatan absorpsi besi dari usus karena eritropoiesis inefektif., 3

Penurunan sintesis kolesterol oleh hati juga terjadi pada pasien dengan anemia berat yang disebabkan oleh hipokolesterolemia. Peningkatan ambilan low density lipoprotein (LDL) oleh makrofag dan histiosit merupakan penyebab utama kadar kolesterol yang rendah pada pasien talasemia beta mayor. Faktor penyebab hipokolesterol penting lainnya adalah peningkatan beberapa sitokin (interleukin-1, interleukin-6, dan tumor necrosis factor-alpha) karena aktivasi kronis dari sistem monosit-makrofag. Hal ini memengaruhi sekresi hepatik dan buangan dari apolipoprotein-B yang mengandung lipoprotein. ${ }^{3}$

Kelebihan besi di pankreas menyebabkan disfungsi sel beta pankreas yang berfungsi dalam regulasi glukosa. Ketidakmampuan sel beta untuk mengompensasi resistensi insulin mengakibatkan hipoinsulinemia relatif, peningkatan aktivitas hormon hepatik lipase. Hal tersebut mengakibatkan disregulasi lipid, terutama pada jalur reverse transport lipid. ${ }^{13,14}$

Penelitian oleh Patne $\mathrm{dkk}^{15}$ di India tahun 2012 mengatakan bahwa terdapat peningkatan kolesterol total dan LDL serta penurunan kolesterol high density lipoprotein (HDL) pada 50 pasien talasemia.
Penelitian di India tahun 2016 mengatakan bahwa terdapat korelasi negatif antara tingginya kadar feritin dengan rendahnya kolesterol HDL. Penelitian Suman $\mathrm{dkk}^{16}$ di India tahun 2016 mengatakan bahwa kadar feritin dengan tingginya kadar trigliserida pada pasien talasemia.

Sejauh pengetahuan kami, belum ada penelitian mengenai profil lipid pada penyandang talasemia beta mayor anak di Indonesia serta korelasinya dengan kadar feritin. Pada penelitian ini, peneliti ingin mengetahui profil lipid, yang terdiri dari serum trigliserida, kolesterol total, HDL, dan $\mathrm{LDL},{ }^{17}$ pada pasien talasemia beta mayor anak serta korelasinya dengan kadar feritin. Penelitian ini dapat menjadi dasar pencegahan terjadinya komplikasi kardiovaskuler pada penyandang talasemia beta mayor. ${ }^{18}$

\section{Metode}

Rancangan penelitian ini adalah penelitian potong lintang dengan pemilihan sampel secara consecutive sampling. Pengambilan data dimulai dari November hingga Desember 2018. Kriteria inklusi adalah pasien talasemia beta mayor anak dengan usia di bawah 18 tahun; kadar feritin di atas $1000 \mathrm{mcg} / \mathrm{L}$; dan data usia dan jenis kelamin sudah terdaftar sebelumnya di rekam medis Poli Hematoonkologi Anak Rumah Sakit Dr. Hasan Sadikin. Kriteria eksklusi adalah adanya penyakit kronis lain, seperti penyakit jantung, ginjal, diabetes mellitus, maupun keganasan yang telah diketahui sebelumnya. Penelitian ini telah memperoleh kelayakan etik dari Komite Etik Rumah Sakit Dr. Hasan Sadikin dengan nomor LB.02.21/X.6.5/331/2018.

Untuk mendapatkan subjek penelitian, setiap penyandang talasemia beta mayor anak yang berkunjung ke Poli Hematoonkologi RSHS diberikan penjelasan kepada orang tua serta melakukan informed consent. Setelah orang tua mengisi data penelitian, subjek penelitian yang sebelumnya telah diketahui kadar feritin dari rekam medis, akan dilakukan pemeriksaan awal mengenai kondisi subjek serta pemeriksaan kadar feritin, serum trigliserida, kolesterol total, HDL, dan LDL di laboratorium patologi klinik RSHS.

Analisis multivariabel bertujuan untuk menggambarkan karakteristik subjek penelitian yang meliputi usia, jenis kelamin, status gizi yang 
didapatkan dari pengukuran lingkar lengan atas dan dilakukan plotting ke tabel lingkar lengan atas WHO, kadar serum feritin, trigliserida, kolseterol total, LDL, dan HDL. Data tersebut disajikan dalam jumlah dan persentase untuk data kategorik, yaitu data usia, jenis kelamin, serta status gizi dan data disajikan dalam rerata, standar deviasi, median, nilai minimum dan maksimum untuk data numerik yaitu kadar serum feritin, trigliserida, kolesterol total, HDL, dan LDL.

Sebelum dilakukan analisis multivariabel, dilakukan uji normalitas data kadar serum feritin, trigliserida, kolesterol total, LDL dan HDL dengan Shapiro-Wilk test dan dinyatakan berdistribusi normal bila nilai $\mathrm{p}>0,05$. Untuk menganalisis korelasi antara kadar serum feritin dengan serum trigliserida, kolesterol total, LDL, dan HDL digunakan korelasi regresi linear Rank-Spearman.

Interpretasi hasil uji hipotesis berdasarkan kekuatan korelasi (r) berdasarkan Guillford, yaitu $0,0-<0,2=$ sangat lemah; $0,2-0,4=$ lemah; $0,4-<0,7=$ sedang, $0,7-<0,9=$ kuat, $0,9-1,0=$ sangat kuat. Arah korelasi positif searah berarti semakin besar nilai satu variabel, semakin besar pula nilai variabel lainnya. Arah korelasi negatif berlawanan arah berarti semakin besar nilai satu variabel, semakin kecil nilai variabel lainnya. Analisis data dilakukan dengan menggunakan program Statistical Product and Service Solution (SPSS) for windows versi 18.0, kemaknaan hasil uji ditentukan berdasarkan nilai $\mathrm{p} \leq 0,05$.

\section{Hasil}

Karakteristik umum subjek penelitian mencakup jenis kelamin, usia subjek, status gizi, usia diagnosis, dan jenis kelasi besi tertera pada Tabel 1. Pada Tabel 1 tertera jumlah sampel 40 pasien, dengan jumlah laki-laki dan perempuan sama rata. Usia pasien antara 10 hingga 14 tahun 18 (45\%) sampel, status gizi baik $26(65 \%)$ sampel, usia saat didiagnosis talasemia beta mayor pada kurang dari 1 tahun $26(65 \%)$, pasien dengan terapi kelasi besi deferiprone 27 (68\%) sampel.

Deskriptif statistik dari berbagai variabel yang diteliti tertera pada Tabel 2. Kadar serum feritin dalam rentang 1067-16500 mcg/L (4328,2), kadar kolesterol total $53-149 \mathrm{mg} / \mathrm{dL}(93,78)$, kadar kolesterol HDL $10-40 \mathrm{mg} / \mathrm{dL} \mathrm{mg} / \mathrm{dL}(20,65)$, kadar kolesterol LDL $20-98 \mathrm{mg} / \mathrm{dL}(52,95)$, dan kadar serum trigliserida $76-304 \mathrm{mg} / \mathrm{dL}(154,95)$.

Korelasi parsial kadar feritin dengan profil lipid dengan usia sebagai kovariat tertera pada Tabel 3 dan Diagram 1. Dari hasil analisis, tidak didapatkan korelasi antara kadar serum feritin dengan kadar serum kolesterol total dan kolesterol LDL ( $p>0,05)$. Terdapat korelasi negatif lemah antara kadar serum feritin terhadap kadar serum kolesterol HDL $(r=-0,349$, $\mathrm{p}=0,029)$. Kadar serum feritin yang semakin tinggi maka akan semakin rendah kadar serum kolesterol HDL. Terdapat korelasi positif sedang antara kadar serum feritin terhadap kadar serum trigliserida $(\mathrm{r}=$ 0,460, $\mathrm{p}=0,003)$. Kadar serum feritin yang semakin

Tabel 1. Karakteristik subjek penelitian $(n=40)$

\begin{tabular}{lcc}
\hline Karakteristik & Jumlah & $\%$ \\
\hline Jenis kelamin & & \\
$\quad$ Laki-laki & 20 & 50 \\
$\quad$ Perempuan & 20 & 50 \\
Usia (tahun) & & \\
$\quad 5$ & 4 & 10 \\
$5-<10$ & 11 & 28 \\
$10-<15$ & 18 & 45 \\
$15-18$ & 7 & 17 \\
Usia diagnosis (tahun) & & \\
$\leq 1$ & 26 & 65 \\
$1-<3$ & 4 & 10 \\
$3-<5$ & 7 & 18 \\
$\quad \geq 5$ & 3 & 7 \\
Jenis kelasi besi & & 32 \\
Exjade & 13 & 68 \\
Ferriprox & 27 & \\
\hline
\end{tabular}

Sari Pediatri, Vol. 21, No. 3, Oktober 2019 
Mutiara Rahmani dkk: Korelasi kadar feritin dengan profil lipid pada penyandang talasemia beta mayor anak

Tabel 2. Deskriptif statistik dari berbagai variabel yang diteliti

\begin{tabular}{lcccc}
\hline Variabel & \multicolumn{3}{c}{ Ukuran statistik } & Uji normalitas data \\
\cline { 2 - 4 } & Rerata (SD) & Median & Rentang & $(\text { Nilai p) })^{*}$ \\
\hline Kadar feritin & $4328,2(3743,0)$ & 3178,7 & $1067-16500$ & $<0,001$ \\
Kolesterol total & $93,78(24,86)$ & 89,5 & $53-149$ & 0,126 \\
Kolesterol HDL & $20,65(6,90)$ & 20,0 & $10-40$ & 0,152 \\
Kolesterol LDL & $52,95(17,73)$ & 49 & $20-98$ & 0,031 \\
Trigliserida & $154,95(58,9)$ & 139,5 & $76-304$ & 0,001 \\
\hline
\end{tabular}

Keterangan: *) berdasarkan uji Shapiro-Wilk; data berdistribusi normal jika p>0,05.

Tabel 3. Korelasi parsial kadar feritin dengan profil lipid (usia sebagai kovariat)

\begin{tabular}{lcc}
\hline Korelasi kadar feritin dengan & $\begin{array}{c}\text { Koefisien korelasi } \\
(\mathrm{r})\end{array}$ & Nilai p \\
\hline Kadar kolesterol total & 0,204 & 0,213 \\
Kolesterol HDL & $-0,349$ & 0,029 \\
Kolesterol LDL & 0,146 & 0,376 \\
Trigliserida & 0,460 & 0,003 \\
\hline
\end{tabular}

Keterangan; $r=$ koefisien korelasi rank Spearman, bermakna bila $\mathrm{p}<0,05$.
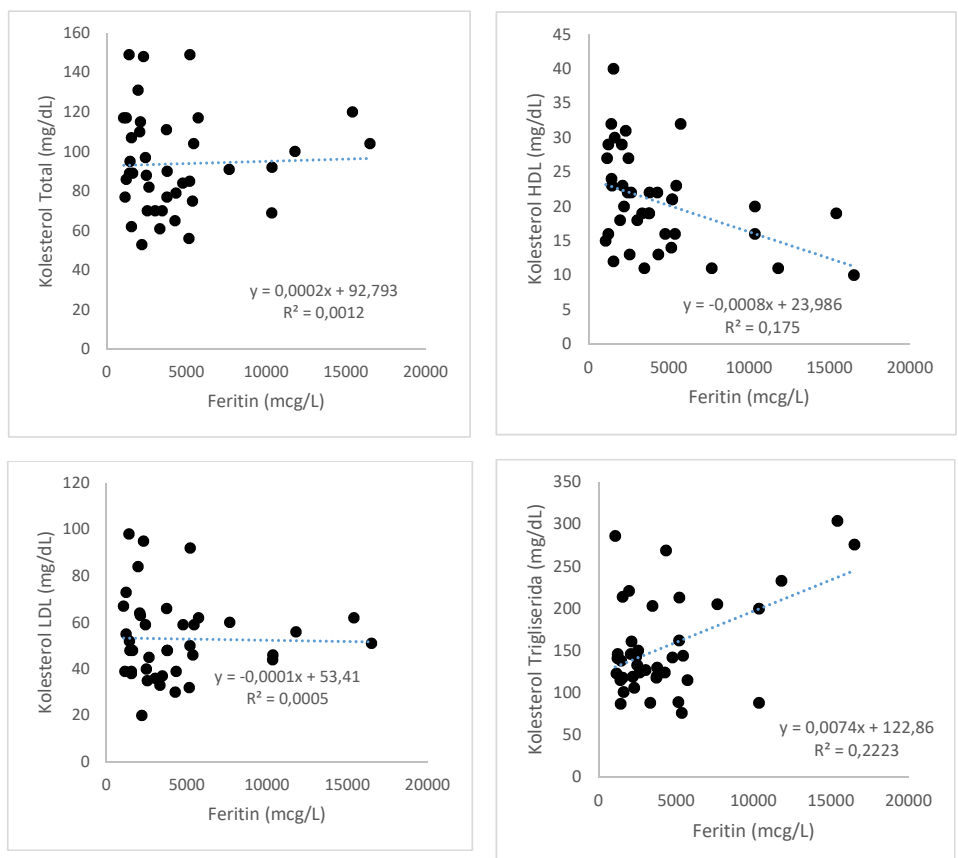

Diagram 1. Diagram baur korelasi kadar feritin dengan profil lipid

tinggi maka semakin tinggi kadar serum trigliserida. Dari diagram 2 ROC Curve antara feritin dan serum trigliserida menunjukkan bahwa dengan kadar serum feritin di atas $5153 \mathrm{ng} / \mathrm{dL}$ memiliki risiko peningkatan serum trigliserida 2,333 kali (sensitivitas 50\%, spesifisitas $84 \%$ ).

\section{Pembahasan}

Modalitas utama talasemia merupakan transfusi darah rutin disertai dengan obat kelasi besi. Tanpa kelasi besi yang adekuat akan menyebabkan kelebihan besi di berbagai organ, seperti hati, pankreas, dan jantung. 
Kelebihan besi pada pasien talasemia disebabkan oleh transfusi darah, hemolisis berlebihan, dan waktu paruh sel darah merah yang menurun. ${ }^{12}$

Hasil penelitian ini tidak mendapatkan korelasi antara kadar serum feritin dengan kadar serum kolesterol total dan kolesterol LDL. Namun, didapatkan korelasi negatif lemah antara kadar serum feritin terhadap kadar serum kolesterol HDL. Seperti pada penelitian oleh Suman $\mathrm{dkk}^{16}$ di India pada tahun 2016. Suman dkk melaporkan korelasi negatif antara kadar feritin yang tinggi dengan kolesterol HDL yang rendah. Pada penelitian tersebut didapatkan bahwa kadar serum kolesterol HDL rendah dan kadar serum trigliserida tinggi pada penyandang talasemia beta mayor anak yang menerima transfusi darah secara rutin dengan kadar serum feritin di atas $1000 \mathrm{mcg} / \mathrm{L}$. Terdapat korelasi negatif antara serum feritin terhadap kolesterol HDL. Terdapat korelasi positif antara serum feritin terhadap serum trigliserida. Salah satu faktor yang mengakibatkan hipokolesterolemia pada pasien talasemia adalah peningkatan sekresi dari berbagai sitokin akibat aktivasi kronis dari sistem monositmakrofag. Hal ini memengaruhi sekresi hepar dan pembuangan apolipoprotein-B yang mengandung lipoprotein. $^{3}$

Banyak faktor yang memengaruhi metabolisme lipid pada penyandang talasemia, seperti kelebihan besi, gangguan hati, dan gangguan hormonal. ${ }^{17,16,19}$

Hati merupakan tempat deposisi besi paling awal pada penyadang talasemia yang rutin mendapatkan transfusi. Kelebihan besi terjadi pada sel hepatosit dan retikuloendotelial dengan produksi radikal bebas melalui reaksi fenton. Radikal bebas ini dapat berkumpul pada jantung, hati, dan organ lain yang mengakibatkan kerusakan jaringan berat. ${ }^{20-24}$ Penurunan sintesis kolesterol dari hati akibat anemia berat juga merupakan faktor yang penting dalam menyebabkan kondisi hipokolesterolemia. Peningkatan ambilan LDL oleh makrofag dan histiosit pada sistem retikuloendotelial menyebabkan kadar kolesterol rendah dalam darah pasien. ${ }^{3}$

Diagram 2 menunjukkan risiko peningkatan trigliserida seiring dengan peningkatan serum feritin. Pada kadar serum feritin di atas $5153 \mathrm{ng} / \mathrm{dL}$ meningkatkan risiko tingginya trigliserida 2,333 kali (sensitivitas $50 \%$, spesifitas $84 \%$ ). Pada penelitian Khubchandani dkk ${ }^{25}$ pada tahun 2014 di Gujarat juga melaporkan risiko peningkatan trigliserida 1,44 kali dibandingkan dengan kontrol.

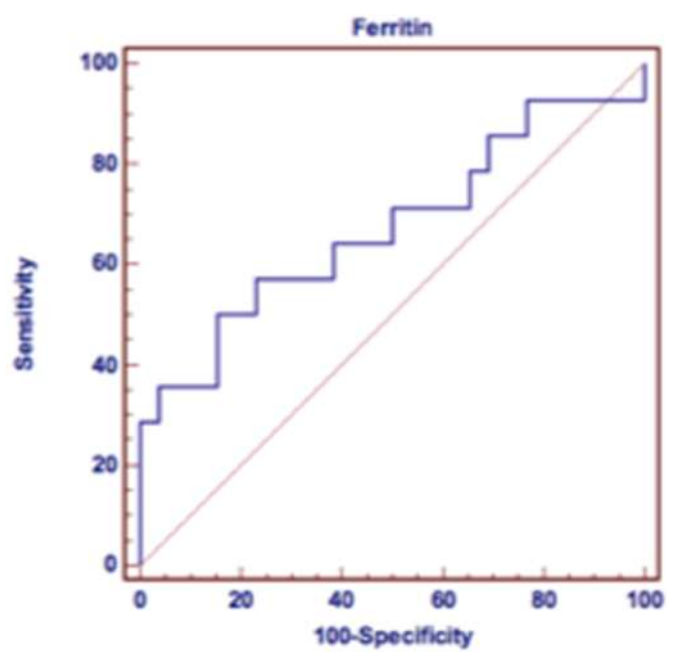

Diagram 2. Kurva ROC antara feritin dan serum trigliserida

Efek lain dari kelebihan zat besi dan transfusi darah berulang adalah induksi dari respon fase akut pada pasien talasemia. Hal tersebut dapat berujung pada perubahan kolesterol LDL menjadi HDL dan mengakibatkan kadar kolesterol LDL rendah. ${ }^{3}$ $\mathrm{Hal}$ ini tidak sesuai dengan penelitian ini yang mungkin disebabkan oleh peran dari kelebihan besi di pankreas berupa kerusakan sel beta yang menyebabkan hipoinsulinemia dan merangsang hepar untuk lebih banyak mensekresi enzim hepatik lipase yang menyebabkan HDL membawa LDL kembali ke hati melalui jalur reverse transport. ${ }^{14}$ Oleh karena itu, dibutuhkan penelitian selanjutnya mengenai pemeriksaan fungsi hati dan pankreas untuk mengetahui organ yang lebih berperan dalam terjadinya disregulasi lipid pada talasemia. Keterbatasan penelitian ini adalah metode yang digunakan adalah potong lintang sehingga diperlukan pemantauan jangka panjang pada penyandang talasemia untuk menilai disfungsi pankreas dan hati yang terjadi.

\section{Kesimpulan}

Pada penelitian ini tidak didapatkan korelasi feritin dengan serum kolesterol total dan LDL, sedangkan terdapat korelasi negatif lemah antara feritin terhadap serum kolesterol HDL serta korelasi positif sedang antara feritin terhadap serum trigliserida. Didapatkan 
Mutiara Rahmani dkk: Korelasi kadar feritin dengan profil lipid pada penyandang talasemia beta mayor anak

korelasi bermakna antara kadar serum feritin terhadap kadar serum kolesterol HDL dan trigliserida.

\section{Daftar pustaka}

1. Renzo G. Beta-thalassemia. Orphanet J Rare Dis 2010;5:1-15.

2. Peters M, Smiers F, Giordano PC. Diagnosis and management of thalassemia. BMJ 2012;344:1-7.

3. Agrawal RNR, Malik R. Study of various biochemical parameters in beta thalassemia major patients and its correlation with serum ferritin level and transfusion index. Indian J Res 2018;7:63-6.

4. Reza Z. Survival analysis and its associated factors of beta thalassemia major in Hamadan Province. IJMS 2015;40:233-40.

5. Rajaeefard AHM, Tabatabaee HR, Hassanzadeh J, dkk. Analysis of survival data in thalassemia patients in Shiraz, Iran. Epidemiol Health 2015;37:1-6.

6. Kementerian Kesehatan (Kemenkes). Pedoman Nasional Pelayanan Kedokteran Tata Laksana Thalasemia. Jakarta: Kemenkes; 2018.h.1-90.

7. Caterina B PM. Complications of thalassemia major and their treatment. Expert Rev Hematol 2011;4:353-66.

8. Karunaratna AMDS RJ, Mudiyanse RM. Iron overload in beta thalassemia major patients. Int J Blood Transfus Immunohematol 2017;7:33-40.

9. Fadlyana E, Elizabeth M, Reniarti L. Correlation between serum ferritin level and growth disorders in children with thalassemia. Am J Clin Med Res 2017;5:31-5.

10. Fajar S. Gangguan fungsi jantung pada thalassemia mayor. Sari Pediatri 2003;5:12-5.

11. Sarmi P, Jannatul A, Talha B, dkk. A study of the prevalence of thalassemia and its correlation with liver function test in different age and sex group in the Chittagong district of Bangladesh. J Basic Clin Pharm 2012;3:352-8.

12. Dey A, Sandip C, Arya S, dkk. Correlation of serum lipid profile with serum iron, TIBC \& ferritin levels in beta thalassemia major patients. Eur J Biol and Med Sci Res 2016;4:17-26.
13. Somboon W, Patcharin K, Sarunyu P, dkk. Acute effects of blood transfusion on insulin sensitivity and pancreatic $\beta$-cell function in children with $\beta$-Thalassemia/ Hemoglobin E Disease. J Clin Res Pediatr Endocrinol 2018;10:1-7.

14. IDAI. Diagnosis dan tata laksana sindrom metabolik pada anak dan remaja. Konsensus Ikatan Dokter Anak Indonesia 2014;1:1-22.

15. Patne PH, Galkwad SB. Lipid abnormalities in patients of beta thalassemia major. Int J Pharm Bio Sci 2012;2:10612.

16. Suman AS, Meena P, Singh J, dkk. Lipid profile in children of $\beta$-thalassemia major and their correlation with serum ferritin. Int J Contemp Pediatr 2017;4:543-7.

17. James S, Mahmood H. Lipids and dyslipoproteinemia. Dalam: Richard A McPherson MRP, penyunting. Henry's Clinical Diagnosis and Management. Philadelphia: Elsevier Saunders; 2011.h.238-59.

18. AIHassanin HE, ElWakeel MA, ElKassas GM, AF dkk. Disturbances of lipid profile and serum ferritin levels in thalassemic children. Curr Sci Int 2015;4:178-83.

19. Delana L. Influence of beta-thalassemia on the phenotypic expression of heterozygous familial hypercholesterolemia : a study of patients with familial hypercholesterolemia from Sardinia. Arterioscier Thromb Vasc Biol 2000;20:236-43.

20. Hartmann C. Hypocholesterolemia in children and adolescents with beta-thalassemia intermedia. J Pediatr 2002;1141:543-7.

21. Ricchi P. Hypocholesterolemia in adult patients with thalassemia: a link with the severity of genotype in thalassemia intermedia patients. Eur J Hematol 2009;82:219-22.

22. Anca V. Serum lipid values in children with beta thalassemia major. Pediatr Terapeut 2012;2:130.

23. Haghoanah S. Serum lipid profiles in patients with betathalassemia major and intermedia in southern Iran. J Res Med Sci 2010;15:127-33.

24. Shalev H. Hypocholesterolemia in chronic anemias with increased erythropoietic activity. Am J Hematol 2007;82:199-202.

25. Khubchandani A, Vijaysinh P, Meghana S, dkk. Estimation of Serum lipid profiles in patients with Beta-thalassemia major. Int J Res Med 2014;3:65-7. 